Kuligowska A. (2016). Scope and assessment of the insurance for members of voluntary fire brigades provided by local government. Copernican Journal of Finance \& Accounting, 5(1), 125-139. http://dx.doi.org/10.12775/CJFA.2016.007

\author{
Angelika Kuligowska* \\ Nicolaus Copernicus University
}

\title{
SCOPE AND ASSESSMENT OF THE INSURANCE FOR MEMBERS OF VOLUNTARY FIRE BRIGADES PROVIDED BY LOCAL GOVERNMENT
}

Keywords: voluntary fire brigade (VFB), accident insurance of voluntary fire brigades, insurance, local government insurance.

\section{J E L Classification: G22, E69.}

Abstract: You can get help in immediate vicinity from the emergency services during a fire, flood or other emergency assistance. Lifeguards can be divided into those who perform their duties professionally and those who are volunteers. Keep in mind that emergency services, such as nurses, fire brigade or mountain rescuers put their lives and health for the salvage of one's wealth or life. Both residents and the authorities should be depend that in their area will be volunteer fire brigade, because they are often the first help. Quick response to the threat may lessen the damage. The aim of the article is to check whether municipalities in Poland provide adequate protection for firefighters, in particular by insurance.

The question of whether local authorities provide sufficient protection for volunteer firefighters. As a consequence, it examines the legal basis to impose compulsory insurance firefighters. In the article analyzed the risks faced by different types of firefighter. It turns out that only a part of taking an active in rescue operations. The information collected compared with the insurance contracts concluded by the municipali-

Date of submission: May 12, 2016; date of acceptance: June 11, 2016

* Contact information: Kuligowska.Angelika@gmail.com, Nicolaus Copernicus University, Gagarina 13a, 87-100 Toruń, Poland, phone: +48796420683. 
ty. The study served insurance documents municipalities in the Kujawsko-Pomorskie districts aleksandrowski, inowrocławski and radziejowski.

\section{INTRODUCTION}

Voluntary fire brigades (VFB) in Poland are among the oldest and the most societally meritorious organizations. Voluntary fire brigades are uniformed units with specialised equipment. Their willingness for selfless help and dedication in the face of danger, earn them recognition and respect in the society. Voluntary fire brigades play one of the most important roles in the protection of life, health, property and environment. Apart of their rescue operations voluntary fire brigades take active part in the life of the local community, they lead educational and cultural activities for the inhabitants. Appropriate equipment and tools are important not only to ensure the flow of actions, but also for the safety of the individuals fighting fires.

The risk of negative events during rescue operations or exercise is one of the major dangers in the work of the members of voluntary fire brigade. The transfer of economic effects on the insurance companies is among the most common methods of risk transfer. It seems justified to conduct examinations, that would allow to find the answer for the question about the shape of insurance protection of the VFBs in Poland. At present there are several possibilities of insuring VFBs, however only one of them is local government' obligatory insurance. In relation to that, other questions become important, like, if the scope of the insurance protection is sufficient and what part of local government's budget is spent on this protection. Conducting the assessment of the present state of insurance is also motivated by the fact, that there are works on a change of the Act on the fire protection of 24 August 1991 (Act of 1991) (hereafter fire protection act), in order to expand the rights of members of voluntary fire brigades by the entitlement to incapacity benefit and rehabilitation benefit (Creation of The Committee of initiative 2015).

\section{RESEARCH METHODOLOGY}

Damage caused by fire or flood are the financial consequences not only for residents but also for the municipalities. The damage will be greater, the greater the financial loss. Public authorities should depend on how the best protection 
from the fire department. The aim of the article is to check whether municipalities in Poland provide adequate protection for fire, in particular by insurance.

Because of the envisioned length of this article, only chosen publications from the vast literature are discussed, those that are related to the insurance of members of voluntary fire brigade. In consequence, it was hypothesised that local government in Poland, while insuring VFBs, restrict the scope of insurance to the obligatory accident insurance. In the commune residents have their houses and other property. But keep in mind that local authorities are also the owners of such buildings, schools, swimming pools, playgrounds. If local authorities provide good working conditions for firefighters, provide better protection for residents and property. At the time of a rapid response to the threat, they do not spend money later to rebuild the damaged property.

Literature analysis and empirical examinations were conducted. National literature, applicable law and general terms and conditions of VFBs insurance were analysed, as well as available source materials on the functioning of VFBs in EU countries.

The practical part of the article showcases the results of the analysis of the documents from tender procedures for insurance of VFBs members: Specifications of the Important Terms of Order of analysed local government and the notice about the result of the procedure. To verify the presented hypothesis, the local government of three poviats of the kujawsko-pomorskie voivodship were examined: aleksandrowski, inowrocławski and radziejowski, in respect of the scope of the insurance protection provided to the members of VFBs by the local government. The local government are serviced by insurance brokers: Eurobrokers sp. z o.o., Inter-Broker Sp. z o.o. and Maximus Broker sp. z o.o. It is important because of the insurance programme the local government were a part of - in case of the same broker, the terms of insurance might be similar. 19 out of 25 local government are serviced by an insurance broker. Most of them, as many as 11, is serviced by Maximus. The legal offices of the brokers are in Torun, where Maximus and Inter-Broker are from and Bydgoszcz - the seat of Eurobrokers. Local government are serviced by the local broker.

Out of the mentioned local government, for the examination were chosen only those, which choose the insurer in an unlimited tender procedure based on Act of 29 January 2004 - Public Procurement Law (Act of 2004). Municipal local government, that do not have their own Voluntary Fire Brigades, could not be analysed. The only exception is the municipal local government of Radzie- 
jow, which has a Municipal Voluntary Fire Brigade. Together, out of 25 local government from three poviats, 17 were subject to a detailed analysis.

\section{VOLUNTARY FIRE BRIGADES IN THE WORLD}

Fire brigades in Poland works as two separate organizations - National Fire Brigade and Voluntary Fire Brigade. According to article 28, paragraph 1 of the act on fire protection, a member of voluntary fire brigade, who took part in a rescue operation or firefighting training organised by the National Fire Brigade or local government, receives a cash equivalent. The member of voluntary fire brigade is not entitled to the equivalent for the time off work, for which they retained the right to remuneration. The amount of remuneration is established by the local government's counsel with a resolution, and it may not exceed $1 / 175$ of average wage ${ }^{1}$ for every hour of participation in a rescue operation or firefighting training. If the remuneration is sufficient and adequate to the firemen work and its dangers, remains a disputable matter.

It is reasonable to compare the rights (privileges) of members of the voluntary fire brigades and their equivalents in other European Union countries. In England (similarly as in great Britain as a whole) each country (voivodship) has its own fire brigades. Each of them has their own individual rules, structure, equipment and independence from other fire brigades. There is no division into two organisations, as it is in Poland (NFB and VFB), but there is a division into voluntary and professional firemen. It should be added, that both groups receive identical set of trainings and equipment (Munir 2012).

In France, there are no voluntary fire brigades as a separate association. Voluntary firemen are contracted in the framework of the firefighting - rescue service. The contract is concluded for five years and it may be renewed many times. Voluntary firemen consist $79 \%$ of the firefighting - rescue service personnel. The employers are obliged under the law to exempt the employees from work for the time of their participation in operations and trainings as members of voluntary fire brigades. Voluntary firemen are entitled to i.a. insurance during their tasks, medical care, same as for professional firemen, equivalent for

1 Applies to the wage announced by the President of Central Statistical Office of Poland in the Official Journal of the Republic of Poland ("Monitor Polski"), according to article 20 point 2 of the Act of 17 December 1998 on old-age pensions and pensions from Social Insurance Fund, before the day of the equivalent expiry. 
the hours of participation in operation, honorary retirement benefit, honorary benefit for a spouse of a fireman that died in action. The amount of the equivalent depends on the rank and for a simple fireman it is $7,45 €$ (French firefighter 2015).

In Germany voluntary fire brigades work as local associations with a status of a public benefit organization under the civil code. National (land) acts on fire protection grant these voluntary fire brigades associations the right to perform the tasks of fire brigades in places, where they are registered and have their headquarters. Voluntary fire brigades are financed by local governments and the main core of fire protection in Germany. Professional fire brigades function only in big cities. In all, fire brigades in Germany consist of over a million of firemen, out of which 890000 belong to Voluntary Fire Brigades. Voluntary firemen are entitled, i.a. to insurance during their tasks and periodic health examinations. Other rights depend on the decision of individual local governments. In most lands and local government units voluntary firemen perform their task without payment (without equivalent). In the past few years some local governments introduced hour or month based equivalents. In the district Aletenburger Land (Thuringia) uniformed voluntary firemen are entitled to free bus rides (Helbig, Leuze 2012).

\section{VFB IN POLAND}

Voluntary fire brigades play one of the most important roles in protecting local communities from the dangers of fire. In the beginning they played a key role by fighting natural disasters, mainly fire, floods. Moreover, they often performed other functions. Many times, being the only social organization at place, they lead political, social and cultural activities.

Organisation of VFB has evolved for ages until nowadays rescue operations. Since ancient times people have fought a battle against fires, however it was not organised, which made its effectiveness not always sufficient. First organization in the form of voluntary fire brigades already arose in middle ages, unfortunately they worked only in bigger cities. Rescue functions were then appointed to city councils and artisan and merchant organizations. Only in 19 century establishment of trained and equipped organizations for putting out fires has begun (Szaflik 1985)

Nowadays, volunteers selflessly serve to protect life, health, property, environment, tradition and national culture. Apart from rescue operations, they 
lead cultural and educational activities for the local community, and pla yactive part in the life of the inhabitants. VFB act in education and prevention, moreover they initiate and take part in humanitarian actions (e.g. honorary blood donation, aid for the disabled, demonstration lessons for pupils).

Voluntary Fire Brigades closely cooperate with organizational units of National Fire Brigades and other entities and institutions to ensure the safety of citizens in the region they operate in (towns and local government) or helping neighbour regions on the basis of operational circuits or mutual aid agreements.

In Poland there are almost 16 thousand VFB units, and in kujawsko-pomorskie voivodship, there are 1347 units. Distribution of units is uneven, the most, 189, are in bydgoski poviat, 107 and 109 are in włocławski and inowrocławski poviats. The fewest, 40 , are in wąbrzeski poviat.

In the ranks of VFB in kujawsko-pomorskie voivodship there are currently almost 45699 thousand members, out of which 26208 are active members, 2415 are honorary members and 8104 are supporting members. These units took part in $38 \%$ of firefighting operations and $37 \%$ of actions to removing the effects of local dangers in 2014 (Regional Branch 2015).

\section{LEgal BASIS OF VFB OPERATION IN POLAND}

It is very important to know how difficult it can be to work as a firefighter. In Poland there are some kind of fire-fighters and a large part of them are not directly involved in the rescue operation. An attempt was made to determine which type of firefighter exposed to health risks. And the same determination, firefighters who need the most support from the local authority.

Voluntary fire brigades function as associations under the Act of 7 April 1989 - Law on associations and the Act of 24 August 1991 on fire protection, and also under the Act of 24 April 2003 - Law on public benefit activity and volunteerism. Besides, the detailed tasks and organisation of VFB are described in their own statutes, adopted by the general assembly of VFB members, agreed with poviat commander.

Legal definition describes fire protection as implementation of projects envisaged by law, whose goal is protection of values deemed the most important by humans: human life and health, property and environment from fires, natural disasters or other local danger. The protection is accomplished in three ways: 
- preventing the start, spreading of fire and natural disasters (prevention) and other local danger,

- providing men and means for fighting these dangers,

- conducting rescue operations.

To define the legitimacy of the insurance of VFB members, it is necessary to define the risks they run. To this end it is worth analysing the scope of duties of each type of members. VFB units consist of active members, supporting members, honorary members and youth firefighting teams (YFT). According to their types, the members have different rights and obligations.

Table 1. Rights and obligations of members of voluntary fire brigades in Poland

\begin{tabular}{|c|c|c|c|}
\hline $\begin{array}{c}\text { Type } \\
\text { of member }\end{array}$ & $\begin{array}{c}\text { Who } \\
\text { may become }\end{array}$ & Rights and obligations & $\begin{array}{c}\text { Membership } \\
\text { fee }\end{array}$ \\
\hline Active / Simple & $\begin{array}{l}\text { A person who } \\
\text { took the appro- } \\
\text { priate oath }\end{array}$ & $\begin{array}{l}\text { - } \quad \text { active part in VFB operations (mainly in rescue } \\
\text { operations during fires, ecological dangers related } \\
\text { with environment protection and other disasters } \\
\text { and dangers), } \\
\text { _ } \quad \text { may use devices and equipment, that are the } \\
\text { property of VFB, } \\
\text { _ } \quad \text { use uniform, insignia and badges }\end{array}$ & Pays \\
\hline Honorary & $\begin{array}{l}\text { Member of VFB } \\
\text { exceptionally } \\
\text { meritorious for } \\
\text { fire protection. } \\
\text { The title of } \\
\text { honorary mem- } \\
\text { ber is awarded } \\
\text { by the general } \\
\text { assembly. }\end{array}$ & $\begin{array}{l}\text { - } \text { may choose and be chosen for the authorities of } \\
\text { _ } \quad \text { may, } \\
\text { to vote, } \\
\text { _ may put forward proposals and motions to VFB } \\
\text { authorities, } \\
\text { _ } \text { may use devices and equipment, that are the pro- } \\
\text { perty of VFB and use uniform and badges, }\end{array}$ & Doesn't pay \\
\hline Supporting & $\begin{array}{l}\text { Natural or legal } \\
\text { person, who } \\
\text { supports the } \\
\text { development } \\
\text { of VFB actions, } \\
\text { financially or in } \\
\text { other way. }\end{array}$ & $\begin{array}{l}\text { (in case of legal person its representative), } \\
\text { - may take part in the general assembly of members } \\
\text { of VFB and be chosen for VFB authorities, } \\
\text { - may use devices and equipment, that are the } \\
\text { property of VFB, }\end{array}$ & $\begin{array}{l}\text { Pays a self decla- } \\
\text { red amount }\end{array}$ \\
\hline $\begin{array}{l}\text { Youth Firefigh- } \\
\text { ting Team }\end{array}$ & $\begin{array}{l}\text { A person who } \\
\text { reached } 12 \text { years } \\
\text { of age, acquired } \\
\text { the agreement } \\
\text { of legal guar- } \\
\text { dians and took } \\
\text { the oath. }\end{array}$ & $\begin{array}{l}\text { - members of YFT in the age of } 16-18 \text { may be chosen } \\
\text { for VFB authorities; } \\
\text { - don't take part in rescue operations of VFB }\end{array}$ & Doesn't pay \\
\hline
\end{tabular}

S o u r c e : own elaboration on the basis of the Statutes of Voluntary Fire Brigade. 
As the above table shows only some of the firefighters involved in the rescue operations. The rest of them is representational and managerial functions. This means that only part of the firefighters may suffer serious damage in the course of action and they should be especially protected.

\section{INSURANCE OF MEMBERS OF VFB}

Units of Voluntary Fire Brigades can use forms of aid foreseen by law, i.a. from the funds forwarded by the Minister of the interior and Administration, from financial resources mentioned in the state budget, from the funds from National Fund of Environmental Protection and Water Management, from the funds forwarded by insurance companies. Furthermore National Fire Brigade is obliged to transfer for free to the voluntary fire brigades, redundant equipment and devices in running condition (Act of 1991).

The biggest source of funding for VFB however are units of local government, which makes them the most important from the point of view of fire brigades. Local government where the VFB has its headquarters is particularly important, as it acts for their benefit. According to article 32 paragraphs 2-3of act on fire protection, the costs of equipping, training and ensuring fighting readiness of VFB and the costs of periodical health examinations are born by local government. Furthermore local government also cover the cost of the firemen insurance.

The insurance of VFB can apply to civil liability insurance for the damage caused by them, but the essential one is the accident insurance of the members of voluntary fire brigades.

Among the examined local government, the most advantageous offers for VFB member insurance were proposed by six insurance companies, out of which the most frequently - 7 times, it was Towarzystwo Ubezpieczeń Wzajemnych "TUW”. The remaining insurance companies are: Uniqa TU S.A., STU Ergo Hestia S.A., Concordia TUW, Polskie Towarzystwo Motorowe TUW and InterRisk S.A. Vienna Insurance Group.

\section{Civil LiABILITY INSURANCE}

Civil liability insurance for damage caused by the units of VFB mainly concerns the damage caused by VFB in relation to the conducted rescue - firefighting operations and owned property, as well as damage caused in the course of train- 
ing activities - to the members of VFB and YFT. The insurance applies to the claims of persons, who because of their participation in rescue operations or training suffered damage to life, health or property.

From the examined local government as many as nine has in the extent of cover of their civil liability insurance an extension for the damage caused by VFB teams in relation to their statutory tasks (rescue operations, firefighting, training, shows, etc.). In the preparation of the extent of insurance cover Maximus Broker took part in case of eight local government. The only exception is local government Koneck (serviced by Inter-Broker Sp. z o.o.), in whose case the extent of cover was reduced to the damage caused by VFB units in the course of rescue - firefighting operations. Besides, two of the examined local government do not have the extension for the damage caused by the actions of the VFB units. The Illustration 1 below shows the limits of the extension of civil liability insurance of particular local government for the actions of VFB.

Illustration 1. Civil liability insurance according to amounts of cover (in PLN).

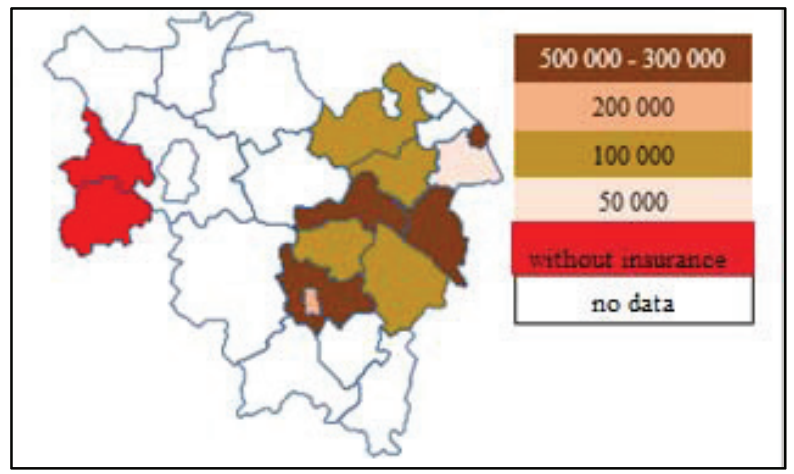

S o u r c e : own elaboration on the basis of Specifications of the Important Terms of Order in the tender procedure for the insurance of the examined local government.

The most common limit is the setting of the amount of cover to 100000 zloty. Exceptionally, in one local government this amount is equal to the amount of cover of the civil liability insurance of the whole local government. Liability insurance is voluntary insurance, but you can see that a large part of the local authority buys this insurance. We do not know the reasons why they make such decisions. A study shows, in any of the surveyed municipalities has not been paid compensation from the insurance. 


\section{ACCIDENT INSURANCE OF THE MEMBERS OF VFB}

The amendment of the Fire Act protection of according to article 32 ensures the compensation for the members of VFB, who in relation to their participation in rescue operations or training suffered damage on health or property. The insurance of VFB members under the article 32 is a legal obligation of a local government.

Apart from the compensation from the insurance company for the VFB and YFT insurance, a member of Voluntary Fire Brigade is entitled to a second compensation if they suffered long term health impairment or died in the course of a rescue operation or training. The compensation is also awarded to the family members in case of death of the VFB member. The compensation is independent from the fact, of this person's use of social insurance. In case of several compensations (e.g. on the basis of social insurance and employment) the beneficiary can acquire only one of their choice. In case of a member of voluntary fire brigade, the compensations may have a form of:

- One time compensation in the event of permanent or long lasting damage to health. The compensation is paid out by the local government, and its amount depends on the percentage of damage to health of the injured, established on the basis of the Act of 30 October 2002 on social insurance in respect of accidents at work and occupational diseases (Journal of Laws of 2002 No 199, Text 1673 as amended). Now it amounts to $730 \mathrm{zt}$ per $1 \%$ of damage to health (Disability pensions and old age pensions).

- pension in respect of complete or partial incapacity for work of the VFB member. The pension is payable by the Social Insurance Institution from the Social Insurance Fund according to the rules, procedures and amounts specified in $\S$ the Act of 30 October 2002 on social insurance in respect of accidents at work and occupational diseases (Journal of Laws of 2002 No 199, Text 1674 as amended). The pension amounts to $120 \%$ of the lowest relevant pension specified in the act on pension benefits from the Social Insurance Fund.

- Onetime compensation in the event of damage to the property of a VFB member participating in a rescue operation or training. The compensation for a member of VFB being a part of National Recue - Firefighting System (NRFS) is paid by the relevant Voivodship Commander of the National Fire Brigade, and for members of other VFB by the local government. The value of damaged property is established according to the 
purchase price in time of calculation of compensation, taking into account the level of wear.

If the member of voluntary fire brigade died as a result of damage to health incurred during a rescue operation or training, the members of their family are entitled to a benefit in the form of: onetime compensation, family pension and also a compensation for a damage to property.

Table 2 shows two possible variants of accident insurance for the members of voluntary fire brigades in Poland. These variants were specified The Innominate Variant ${ }^{2}$ is obligatory for every local government having VFB on its territory.

Table 2. Accident insurance of members of VFB

\begin{tabular}{|l|l|l|}
\hline \hline & \multicolumn{1}{|c|}{ Innominate variant } & \multicolumn{1}{|c|}{ Nominate variant } \\
\hline \hline $\begin{array}{l}\text { Legal basis: } \\
\text { Act of 24 August 1991 } \\
\text { on fire security }\end{array}$ & Article 32 paragraph 3 point 2 of the act & $\begin{array}{l}\text { Article 26 paragraph 1 point 1 and para- } \\
\text { graph 2 point 1. }\end{array}$ \\
\hline Beneficiary & Named FVB Units & Firemen stated by name and surname \\
\hline Insurance cover & $\begin{array}{l}\text { Accidents resulting in damage to body } \\
\text { or health, causing lasting damage } \\
\text { to health or death of the insured. }\end{array}$ & $\begin{array}{l}\text { Accidents resulting in damage to body } \\
\text { or health, causing lasting or permanent } \\
\text { damage to health or death of the insured. }\end{array}$ \\
\hline Insurance amount & $\begin{array}{l}\text { Individually defined, due to 100\% da- } \\
\text { mage to health ranges from 1 000 zł } \\
\text { to 100 000 zł / 1 person }\end{array}$ & $\begin{array}{l}\text { Set for every insured person in the amount } \\
\text { of the average monthly wage }\end{array}$ \\
\hline Compensation & $\begin{array}{l}\text { According to the arrangements. } \\
100 \% \text { for death and permanent damage } \\
\text { to health. }\end{array}$ & $\begin{array}{l}\text { The compensation is set according to the } \\
\text { regulations of the Act of 30 October } 2002 \\
\text { on social insurance in respect of accidents } \\
\text { at work and occupational diseases }\end{array}$ \\
\hline \hline
\end{tabular}

* Applies to the average wage in national economy in the preceding year, announced in Official Journal of the Polish Republic "Monitor Polski" by the President of Central Statistical Office of Poland, used from the second quarter of each year, for one year.

S o u r c e : own elaboration on the basis of fire protection act and available General Terms and Conditions of Accident Insurance for Members of Voluntary Fire Brigades of PZU SA, GT\&C of Accident Insurance of Compensa TU S.A. VIG and GT\&C of Accident Insurance of Towarzystwo Ubezpieczeń Wzajemnych „TUW”.

2 According to the act, the insurance may be „either nominate or collective innominate". The innominate form is understood as a one, where in the application and in the insurance policy there is only a name of VFB (in case of the insurance of a single person). 
The Act defines two types of insurance for volunteer firefighters. Those who take part in rescue operations should have two insurance. It remains to see if the local authorities who are obliged to conclude insurance contracts do it.

Illustration 2 shows the scope of accident insurance in the examined local government. All local government insure the members of FVB in the so called nominate variant. The insured members take active part in rescue operations, that is why there is greater risk of damage than in case of honorary or supporting members. However, it should be considered, that during training, meetings, competitions and other FVB activities, there is also a possibility of damage, e.g. a person can fall down and get hurt during a solemn speech. Therefore the statutory obligation of local government forces them to insure all VFB members

Illustration 2. Share of VFB members insured in a nominate variant in the number of the insured

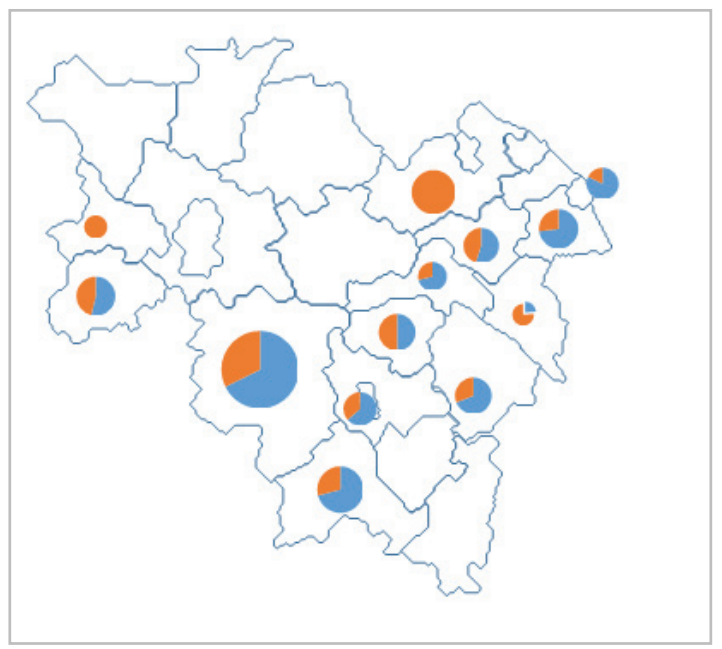

S o u r c e : own elaboration on the basis of a performed examination.

The information shown on the Illustration 3 picture the scope in which the examined local government insure the VFB units. Local government that after preliminary analysis were further analysed are marked with grey. In case of nine out of fourteen local government, they have the full scope of insurance: Civil Liability Insurance and Accident Insurance in two variants and it is 65\% of all examined local government. Twelve local government have the Accident 
Insurance of VFB members in the obligatory scope and thirteen in the additional scope.

Illustration 3. The scope of VFB units insurance provided by local government

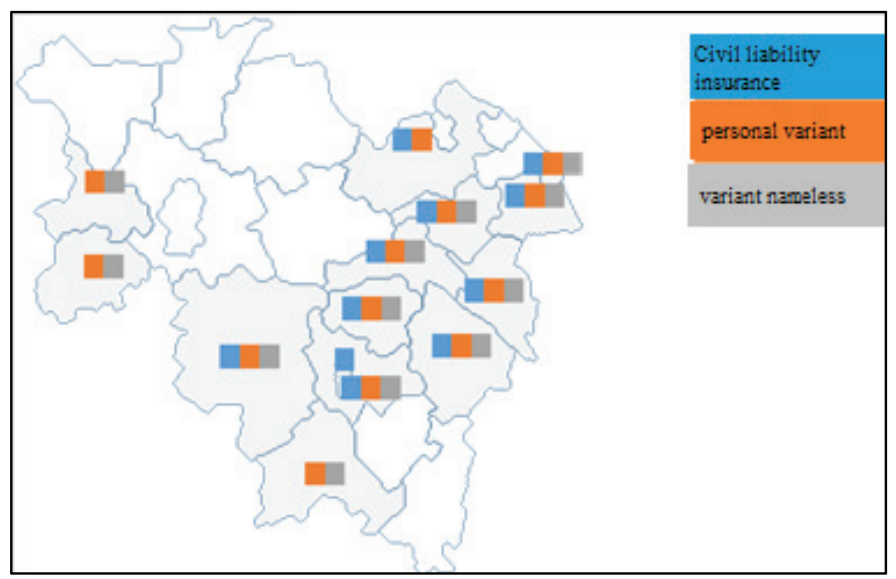

S o u r c e : own elaboration on the basis of a performed examination.

Should also check whether there so far the damage covered by insurance in the surveyed municipalities. If damage occurred whether it was compensation payments and how much.

Table 3. Compensations from accident insurance of VFB

\begin{tabular}{|c|c|c|c|c|}
\hline \hline Year & Number of accidents & Amount paid & Number of denials & Reserves \\
\hline \hline 2010 & 2 & $1300,00 \mathrm{zł}$ & Non & Non \\
\hline 2013 & 2 & $4111,32 \mathrm{z \nmid}$ & Non \\
\hline \hline
\end{tabular}

S o u r c e : own elaboration.

Table 3 shows the list of compensations, that were paid in recent years to the local government. In all examined local government only in case of two there were compensations paid due to accident insurance. As we see the number of claims is not high, but the amount of compensation is not too large. Unfortunately, we do not know the reason of damage, the only thing known is that 
the damages are the result of an accident. Besides, these are all claims reported to insurers, as there were no refusals.

\section{CONCLUSIONS}

There are no reasons to acknowledge the hypothesis stated in the beginning of this article, that the local government only insure the voluntary fire brigades in the obligatory scope. Please note that the firefighters are volunteers and receive no payment for exercise, and for taking part in rescue symbolic amount. In the case of injury, they can get the equivalent of insurance. It is important that local authorities seek to ensure the best conditions of insurance for them. By paying the insurance premium, they will not have to pay compensation. Good conditions for firefighters translate into good protect wealth of the municipality. Authorities and residents will spend less money for the reconstruction the property. Eventually, more money will be in your budget. The performed examination allows also for further, interesting conclusions:

- 19 out of 25 examined local government is served by an insurance broker, out of which as many as 11 by Maximus,

- all local government having VFB in their area, insure them,

- the insurer that was chosen the most often was Towarzystwo Ubezpieczeń Wzajemnych „TUW”,

- the most common insurance amount in case of civil liability insurance for VFB units activities is 100000 zloty,

- in all the examined local government only in two cases there were compensations paid from the accident insurance,

- all local government insure the members of VFB in the so called nominate variant,

- in case of nine out of fourteen local government they have the full scope of the insurance: civil liability insurance and accident insurance in two variants,

- 12 municipalities have the accident insurance for VFB members in the obligatory scope and 13 in the additional scope.

Detailed analysis of the insurance documents of the VFB units allows for a positive rating of the scope of insurance protection provided by local government. Local government insure the liability for damage caused by the members of VFB during rescue operations or training. Furthermore they provide a wide scope of accident insurance for the members of VFB. 


\section{REFERENCES}

Act of 24 April 2003 on Public Benefit and Volunteer Work, Journal of Laws of 2014, text 1118. Act of 24 August 1991 r. on fire protection, Dz. U. z 2009 r. poz. 1380 as amended.

Act of 29 January 2004 - Public Procurement Law, Journal of Laws of 2013, text 907 as amended.

Act of 29 January 2004 - Public Procurement Law, Journal of Laws text 177 as amended.

Act of 30 October 2002 on social insurance in respect of accidents at work and occupational diseases, Journal of Laws of 2002 Text 1674 as amended.

Act of 7 April 1989 - The Associations Act, Journal of Laws of 2001 r. text 855 as amended.

Brice, A. (2015). French firefighter mortality: Analysis over a 30-year period, American Journal of Industrial Medicine, Volume 58, Issue 4, April 2015.

Draft of Act of 2014 on changing the fire protection act, http://twojruch.eu/wp-content/uploads/2014/10/Projekt-ustawy-OSP.pdf (accessed: 10.01.2015).

General Terms and Conditions of Accident Insurance for Members of Voluntary Fire Brigades of PZU SA.

General Terms and Conditions of Accident Insurance for Members of Voluntary Fire Brigades of Compensa TU S.A. VIG.

General Terms and Conditions of Accident Insurance for Members of Voluntary Fire Brigades of Towarzystwo Ubezpieczeń Wzajemnych „TUW”.

Helbig, M., \& Leuze, K. (2012). Ich will Feuerwehrmann werden!, KZfSS Kölner Zeitschrift für Soziologie und Sozialpsychologie, Volume 64, Issue 1.

Kurzępa, B. (2010). Ustawa o ochronie przeciwpożarowej z komentarzem. TARBONUS, Krakow-Tarnobrzeg.

Regional Branch of the Volunteer Brigades Poland Kujawsko-Pomorskie, http://www. zosprp.torun.pl/strona.php/1_oddzial.html (accessed: 25.02.2015).

Munir, F., Clemes, S., Houdmont, J., \& Randall, R. (2012). Overweight and obesity in UK firefighters, Occupational Medicine Volume 62, Issue 5.

Powołanie Komitetu Inicjatywy Ustawodawczej „Ustawy o zmianie ustawy z dnia 24 sierpnia 1991 r. o ochronie przeciwpożarowej". http://www.zosprp.opole.pl/aktualnosci/2014/25/zmieniamy_usta we.pdf, (accessed: 26.04.2015).

Specifications of the Important Terms of Order of Local government: Aleksandrow Kujawski, Aleksandrow Kujawski Local government Miejska, Bądkowo, Bytoń, Dobre, Miasto Inowrocław, Janikowo, Koneck, Kruszwica, Nieszawa, Osięciny, Pakość, Piotrkow Kujawski, Raciązek, Radziejow, Radziejow Miasto, Rojewo, Waganiec, Zakrzewo.

Strażacy ochotnicy walczą o zmianę ustawy o ochronie przeciwpożarowej, http://pisz. wm.pl/223796, Strazacy-ochotnicy-walcza-o-zmiane-ustawy-o-ochronie-przeciwpozarowej.html\#axzz3bYHO2m Qf (accessed: 26.04.2015).

Szaflik, J. R. (1985). Dzieje ochotniczych straży pożarnych. Ludowa Spółdzielnia Wydawnicza, Warszawa.

ZOSP R.P. - number of VFB in Poland, http://www.kppspblonie.pl/tematy_szkolenie_ osp_starnowski_2008.pdf (accessed: 15.01.2015). 